\title{
Expression of catalase and retinoblastoma-related protein genes associates with cell death processes in Scots pine zygotic embryogenesis
}

\author{
Jaana Vuosku ${ }^{1,3^{*}}$, Suvi Sutela1, Johanna Kestilä', Anne Jokela', Tytti Sarjala² and Hely Häggman
}

\begin{abstract}
Background: The cell cycle and cellular oxidative stress responses are tightly controlled for proper growth and development of Scots pine (Pinus sylvestris L.) seed. Programmed cell death (PCD) is an integral part of the embryogenesis during which megagametophyte cells in the embryo surrounding region (ESR) and cells in the nucellar layers face death. In the present study, we show both the tissue and developmental stage specific expression of the genes encoding the autophagy related ATG5, catalase (CAT), and retinoblastoma related protein (RBR) as well as the connection between the gene expressions and cell death programs.
\end{abstract}

Results: We found strong CAT expression in the cells of the developing embryo throughout the embryogenesis as well as in the cells of the megagametophyte and the nucellar layers at the early embryogeny. The CAT expression was found to overlap with both the ATG5 expression and hydrogen peroxide localization. At the late embryogeny, CAT expression diminished in the dying cells of the nucellar layers as well as in megagametophyte cells, showing the first signs of incipient cell death. Accumulation of starch and minor RBR expression were characteristic of megagametophyte cells in the ESR, whereas strong RBR expression was found in the cells of the nucellar layers at the late embryogeny.

Conclusions: Our results suggest that ATG5, CAT, and RBR are involved in the Scots pine embryogenesis and cell death processes. CAT seems to protect cells against hydrogen peroxide accumulation and oxidative stress related cell death especially during active metabolism. The opposite expression of RBR in the ESR and nucellar layers alongside morphological characteristics emphasizes the different type of the cell death processes in these tissues. Furthermore, the changes in ATG5 and RBR expressions specifically in the megagametophyte cells dying by necrotic cell death suggest the genetic regulation of developmental necrosis in Scots pine embryogenesis.

Keywords: Autophagy, Catalase, Conifer, Developmental cell death, Embryogenesis, Megagametophyte, Pinus, Retinoblastoma-related protein, Scots pine, Seed development

\section{Background}

In multicellular organisms such as plants, the organized destruction of cells by programmed cell death (PCD) is essential for body plans and specific organ shapes as well as for removing damaged or infected cells [1-4]. In plants, different cell death types are often defined by morphological characteristics because precise molecular

\footnotetext{
* Correspondence: jaana.vuosku@luke.fi

${ }^{1}$ Genetics and Physiology Unit, University of Oulu, P.O. Box 3000, FI-90014 Oulu, Finland

${ }^{3}$ Current address: Natural Resources Institute Finland (Luke), Rovaniemi Unit, Fl-96301 Rovaniemi, Finland

Full list of author information is available at the end of the article
}

mechanisms behind the regulation and execution of cell death processes are still poorly known $[5,6]$. Two classes of cell death, vacuolar cell death and necrosis, have been suggested for plants but the terms are not unambiguous $[6,7]$. Examples of vacuolar cell death are found during embryo, organ and tissue morphogenesis and senescence, whereas necrosis is most usually induced by a variety of abiotic stresses and by successful recognition of a pathogen during the hypersensitive response [6,8]. However, necrosis is no longer considered to be an uncontrolled process, but necrotic cell death can also be a regulated event that contributes to the development and to the maintenance of tissue and organismal integrity [9-11]. In plants, the roles 
of nucleases and proteases in PCD are evident $[12,13]$ but the cell death processes also involve many other molecular mechanisms such as catalase [14] and the retinoblastoma related proteins [15] which are required to maintain cellular homeostasis and thus may be difficult to identify as actual cell death effectors.

The reactive oxygen species (ROS) contribute to the induction, signalling and execution of plant cell death [16-18]. Hydrogen peroxide $\left(\mathrm{H}_{2} \mathrm{O}_{2}\right)$, the most stable ROS [19], has received particular attention as a signal molecule involved in the regulation of essential biological functions such as cell death, pathogen responses, and gene expression [16,20-23]. $\mathrm{H}_{2} \mathrm{O}_{2}$ is a toxic byproduct of cell metabolism and $\mathrm{H}_{2} \mathrm{O}_{2}$ generation from a variety of cellular processes increases in response to numerous developmental signals and biotic and abiotic stimulants [24]. While plants contain several types of $\mathrm{H}_{2} \mathrm{O}_{2}$-metabolizing proteins, catalases (CAT, hydrogen peroxide oxidoreductase, EC 1.11.1.6) are highly active peroxisomal enzymes which express high specificity towards $\mathrm{H}_{2} \mathrm{O}_{2}$ and protect cells from the toxic effects by the conversion of $\mathrm{H}_{2} \mathrm{O}_{2}$ into water and molecular oxygen [25]. It has been suggested that impact of $\mathrm{H}_{2} \mathrm{O}_{2}$ is strongly influenced by the extent of accumulation of $\mathrm{H}_{2} \mathrm{O}_{2}$ allowed by antioxidant enzymes such as CAT. This has been shown in Chlamydomonas reinhardtii where a reversible partial inactivation of CAT correlates with a transient increase in the level of $\mathrm{H}_{2} \mathrm{O}_{2}$. The concentration range seems to be necessary to activate $\mathrm{H}_{2} \mathrm{O}_{2}$-dependent signaling pathways stimulating the expression of $\mathrm{H}_{2} \mathrm{O}_{2}$ responsive genes [26]. Furthermore, the direct interaction of CAT with ROS could allow CAT to act as a molecular link between ROS and the promotion of autophagy-dependent cell death [14].

In plants, the retinoblastoma related proteins (RBR) regulate the progression of cell cycle and transcription via chromatin-modifiers and, furthermore, function in promotion of cell differentiation [27]. Recently, RBR1 was found to control also cell death in maize (Zea mays L.) endosperm cells [15]. The plant RBR proteins are homologs of retinoblastoma susceptibility gene products (pRB) firstly discovered in human cells [28]. The pRB proteins are activated by phosphorylation and their $\mathrm{A} / \mathrm{B}$ pocket domain enables them to interact with more than 100 proteins [29]. The interaction of hypophosphorylated RBR with E2F and DP transcription factors prevents cell division by suppressing the transition from $\mathrm{G} 1$ to $\mathrm{S}$ phase in the cell cycle [27]. In plants, $R B R$ genes are conserved and they have been found from green algae, bryophytes, lycophytes and from both monocot and dicot angiosperm species [27,30]. In our previous study, we showed that the RBR/E2F pathway operates also in conifers by presenting the expression of $R B R$ and $E 2 F$ genes in in vitro cultured Scots pine (Pinus sylvestris L.) embryogenic cells [31].
PCD is an integral part of the seed development in angiosperm and gymnosperm species (e.g. [32-35]). In gymnosperms, the Scots pine seed represents a welldocumented embryogenesis with coordinated action of several distinct cell death programs. The fertilization of several eggs [36] and furthermore the cleavage of polyzygotic embryos [37] leads to the presence of several embryos in a young seed. However, only the dominant embryo survives, whereas the subordinate embryos die via PCD during the seed development [34]. Embryos grow and develop inside the corrosion cavity of the megagametophyte tissue which functions as a nutrient source of embryos i.e. being congruent with the endosperm of angiosperms [38]. Throughout the embryo development, the megagametophyte cells in the embryo surrounding region (ESR) are destroyed by morphologically necrotic cell death [35]. Additionally, the cells in the megagametophyte surrounding nucellar layers die during the seed development [35,39] providing nutrition for the surrounding tissues and later functioning as a barrier against water and fungi $[40,41]$. The importance of caspase-like VEIDase activity, type II metacaspases, and Tad-D nuclease have been perceived in cell death during Scots pine and Norway spruce (Picea abies (L.) Karst.) embryogenesis $[35,42,43]$. In conifers, the autophagy related (ATG) proteins are essential for vacuolar cell death and for instance, in Norway spruce, depletion of ATG5 and ATG6 causes aberrations in the development of suspensors [44].

Here, we study the progress of two distinct types of cell death programs and reveal the link between PCD and the expression of $C A T$ and $R B R$ genes which are typically considered as maintainers of cellular homeostasis. We focus on the cell death processes in the ESR and nucellar layers during the Scots pine seed development, and show that ATG5 previously connected to the regulation of vacuolar cell death also expresses in the cells destroyed via necrotic-like cell death.

\section{Methods}

\section{Immature and mature Scots pine seeds}

One-year-old immature seed cones were collected during the growing period in July from an open-pollinated elite Scots pine (Pinus sylvestris L.) clone, K818, growing in the Scots pine clone collection in Punkaharju, Finland $\left(61^{\circ} 48^{\prime} \mathrm{N} ; 29^{\circ} 17^{\prime} \mathrm{E}\right)$. Immature Scots pine seeds were dissected from the developing cones. For the anatomical observations, for the detection of PCD and for the localization of proteins, starch, and mRNA transcripts of $A T G 5, C A T, R B R$ and $\beta$-glucosidase ( $\beta G$, EC 3.2.1.21), the seed coats were removed and immature seeds were fixed immediately and embedded in paraffin as described below. For the gene expression studies, immature seeds were stored in liquid nitrogen until use. 
Mature Scots pine cones were collected from the same grafts as the immature cones in late fall of the same growing season. Mature Scots pine seeds were surface sterilized with 3\% Plant Preservative Mixture (Plant Cell Technology) overnight and placed thereafter on moist filter paper and let to imbibe at room temperature (RT) for two days. Thereafter, seeds were opened with a scalpel, seed coats were removed, and the embryos and megagametophytes were separated from each other for the gene expression analysis. For the localization of ATG5 and CAT mRNA transcripts mature seeds were fixed as described below.

\section{Anatomical and histochemical observations}

Developing and imbibed mature Scots pine seeds with and without seed coats were dissected for the histochemical localization of $\mathrm{H}_{2} \mathrm{O}_{2}$ and peroxidase. The 3,5,3'5'-tetramethylbenzidine (TMB) is oxidised by peroxidases in a reaction where $\mathrm{H}_{2} \mathrm{O}_{2}$ acts as a hydrogen acceptor, and thus, TMB can be used to localize $\mathrm{H}_{2} \mathrm{O}_{2}$ and peroxidases [45]. For the $\mathrm{H}_{2} \mathrm{O}_{2}$ localization the seeds were incubated in $50 \mathrm{mM}$ Trisacetate-buffer ( $\mathrm{pH} 5.0$ ), which contained $0.1 \mathrm{mg} / \mathrm{ml}$ $3,5,3^{\prime}, 5^{\prime}-\mathrm{TMB}-\mathrm{HCl}$ [45], at $\mathrm{RT}$ at least for $45 \mathrm{~min}$. In addition, seeds were treated with $3 \% \mathrm{H}_{2} \mathrm{O}_{2}$ in $1 \mathrm{x}$ phosphate-buffered saline (PBS) buffer (10 mM phosphate, $150 \mathrm{mM} \mathrm{NaCl}, \mathrm{pH}$ 7.4) for $10 \mathrm{~min}$ prior to the histochemical staining for the peroxidase location. Negative controls were incubated in $50 \mathrm{mM}$ Tris-acetate-buffer.

The DAB (3,3'-diaminobenzidine) Peroxidase Substrate kit (Vector Laboratories) was used in localizing peroxidase activity following manufacturer's instructions. The dissected seeds were incubated for two or three min at $\mathrm{RT}$ in reaction mixture. The DAB Peroxidase Substrate reaction mixture contains $\mathrm{H}_{2} \mathrm{O}_{2}$ which oxidizes $\mathrm{DAB}$, and subsequently generates a dark brown reaction product when peroxidases are present. Negative controls were incubated in reaction mixture without DAB. The blocking of peroxidase activity was attempted by incubating seed material in $1 \% \mathrm{H}_{2} \mathrm{O}_{2}$ at $\mathrm{RT}$ for $10 \mathrm{~min}$. The sections were examined by a stereo microscope (Stemi DV4, Carl Zeiss) and imaged with a digital camera (Nikon Coolpix 950, Japan).

Developing and mature Scots pine seeds were fixed for studying the anatomical features of the embryos and for in situ mRNA hybridization analyses using the following protocol from fixation to coverslip mounting. Tissues were fixed in $4 \%(\mathrm{w} / \mathrm{v}) p$-formaldehyde in $1 \mathrm{x}$ PBS. After dehydration with a graded series of ethanol, ethanol was replaced by tertiary butanol and then gradually by paraffin. Sections ( 5 and $7 \mu \mathrm{m}$ ) were cut from the embedded samples with a microtome, mounted on SuperFrost ${ }^{\oplus}$ Plus slides (Menzel-Glaser) and fixed by drying overnight at $40^{\circ} \mathrm{C}$.
The paraffin sections were dewaxed in Histochoice (Sigma) and rehydrated through a graded series of ethanol. To study the developmental stage of the embryos, the preparates were stained with toluidine blue (0.05\% toluidine blue in $\left.\mathrm{H}_{2} \mathrm{O}\right)$. According to Singh [46] Scots pine embryogenesis is divided into three different phases, proembyogeny, early embryogeny and late embryogeny. Here, we studied the early embryogeny which initiates with the elongation of the suspensor system and terminates with the appearance of the root meristem (Figure 1A) and the late embryogeny which contains the establishment of root and shoot meristems and the maturation of the leading embryo (Figure 1B). For the protein and starch visualization the sections were stained with $0.2 \%$ amido black [47] and with $0.5 \%$ potassium iodide-iodine (IKI) [48], respectively. All sections were studied with a light microscope (Nikon Eclipse E600) and photographed with a Qimaging Micropublisher 5.0 RTV digital camera. Adobe Photoshop CS was used to adjust contrast, brightness and colour uniformly to entire images.

\section{TUNEL assay}

Nuclear DNA fragmentation, i.e. DNA strand breaks leaving free $3^{\prime}-\mathrm{OH}$ termini, was shown by the TUNEL (terminal deoxyribonucleotidyl transferase (TdT)-mediated deoxyuridine triphosphate (dUTP) nick end labelling) assay. The dewaxed and rehydrated sections were digested with $10 \mu \mathrm{g} / \mathrm{ml}$ proteinase-K (Roche) for $30 \mathrm{~min}$ and two washings with PBS. The sections were labelled with TMR red (red fluorescence) using in situ cell death detection kit (Roche) according to the manufacturer's protocol. Prior to the labelling procedure, the positive control sections were incubated with DNase I recombinant (Roche) to induce DNA strand breaks. The label solution without terminal transferase, instead of the TUNEL reaction mixture, was used as a negative control. The labelled sections were examined with a confocal laser scanning microscope (LSM 5 Pascal, Carl Zeiss) with an HBO 100 mercury lamp and using the HeNe laser $543 \mathrm{~nm}$ line, dichroic beam splitter (HFT 488/543/633; Carl Zeiss) and LP 560 emission filter (Carl Zeiss).

\section{RNA extraction, reverse transcription and cDNA cloning}

Total RNA was extracted using the automated magneticbased KingFisher ${ }^{\text {Ts }} \mathrm{mL}$ method (Thermo Electron Corporation) with the MagExtractor ${ }^{\ominus}$ total RNA purification kit (Toyobo) according to the manufacturer's instructions. The RNA samples were treated with RNase-free DNase (Invitrogen) at RT for $15 \mathrm{~min}$ for the elimination of contaminating genomic DNA. Thereafter the RNA samples were purified with the NucleoSpin ${ }^{\oplus}$ RNA Clean-Up kit (Macherey-Nagel). The RNA yields were measured three times with $\mathrm{OD}_{260}$ 


\section{A}

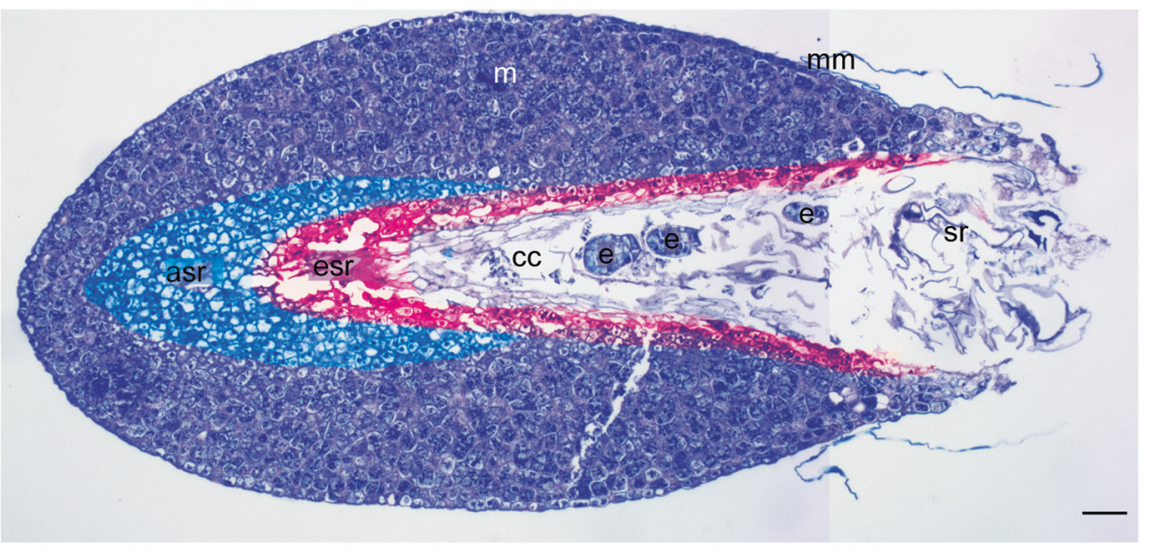

B

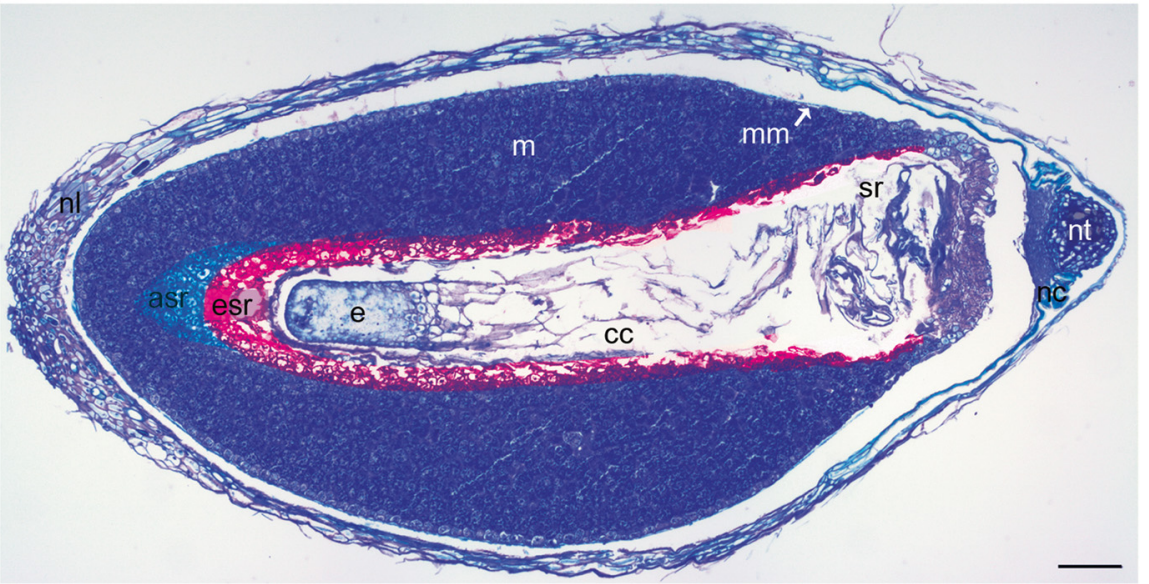

Figure 1 Early and late developmental stages of Scots pine embryogenesis. (A) The dominant embryo and subordinate embryos in the corrosion cavity at the early embryogeny surrounded by the embryo surrounding region (esr) of the megagametophyte highlighted with red color. The arrow-shaped region (asr) of the megagametophyte outside the esr highlighted with blue color. (B) The dominant embryo in the corrosion cavity at the late embryogeny. The esr of the megagametophyte highlighted with red color and asr highlighted with blue color. asr = arrow-shaped region, $c c=$ corrosion cavity, e = embryo, esr = embryo surrounding region, $m=$ megagametophyte, $m m=$ megaspore membranes, $\mathrm{nc}=$ nucellar cap, $\mathrm{nl}=$ nucellar layers, $\mathrm{nt}=$ cellular nucellus, sr = suspensor remnants. Bars: $100 \mu \mathrm{m}$.

analysis using NanoDrop ND1000 spectrophotometer (NanoDrop Technologies), and $1 \mu \mathrm{g}$ of each RNA sample was subsequently used for the cDNA synthesis. cDNA was reverse-transcribed from an anchored oligo-dT primer by SuperScript II reverse transcriptase (Invitrogen) using standard methods in a reaction volume of $20 \mu$ l. Fragments of the putative Scots pine ATG5 and cell wall associated $\beta G$ were amplified by standard PCR using cDNA from immature seeds as a template, gene specific primers (Additional file 1: Table S1) and DyNAzyme ${ }^{\mathrm{mw}} \mathrm{EXT}$ polymerase (Finnzymes). The fragments with appropriate length were gel-purified by Montage DNA Gel Extraction Kit (Millipore Corporation), cloned by TOPO TA Cloning Kit (Invitrogen) and sequenced by an Applied Biosystems 3730 DNA analyzer.

\section{In situ mRNA hybridization analysis}

The RNA probes for the in situ mRNA hybridization analyses of $A T G 5, C A T, R B R$ and $\beta G$ transcripts in developing and mature seeds were prepared using a PCR-based technique [49]. The T7 RNA polymerase promoter sequence (TAATACGACTCACTATAGGG) was introduced at the 5 'ends of the gene-specific primers (Additional file 1: Table S2). The downstream primers contained an artificially introduced T7 promoter at its $5^{\prime}$ end, which enabled the synthesis of antisense transcripts. The upstream primers containing T7 promoters at the $5^{\prime}$ ends was used for the synthesis of sense transcripts, i.e. as negative control.

The PCR fragment representing the coding region of either ATG5, CAT, RBR or $\beta G$ was produced under standard PCR conditions by DyNAzyme ${ }^{\mathrm{Tm}} E X T$ polymerase (Finnzymes) using plasmid DNA containing the cDNA in question as a template. The PCR fragment was gel-purified (DNA Gel Extraction Kit, Millipore Corporation) and 250 ng was subsequently used as a template DNA for in vitro transcription by T7 RNA polymerase (Invitrogen), incorporating dig-UTP via DIG RNA labelling Mix (Roche 
Molecular Biochemicals). Template DNA was digested with four units of RNase-free DNase (Invitrogen) in a reaction volume of $20 \mu \mathrm{l}$ at $37^{\circ} \mathrm{C}$ for $10 \mathrm{~min}$, the probe was precipitated and the yield of the DIG-labeled RNA probe was estimated by comparing the intensity of the sample to the defined controls made with DIG-labelled control RNA (Roche Molecular Biochemicals).

The sections were dewaxed, treated with Proteinase $\mathrm{K}$ (Finnzymes, $1 \mu \mathrm{g} / \mathrm{ml}$ in $100 \mathrm{mM}$ Tris/ $\mathrm{HCl}, 50 \mathrm{mM}$ $\mathrm{Na}_{2}$ EDTA, $\mathrm{pH} 7.5$ ) at $37^{\circ} \mathrm{C}$ for $30 \mathrm{~min}$ and dehydrated in a graded series of ethanol up to absolute. The slides were dried in a vacuum for $1 \mathrm{~h}$. For the hybridization, $250 \mu \mathrm{l}$ of hybridization mixture was added to the sections, mounted under coverslips and incubated in a water atmosphere at $55^{\circ} \mathrm{C}$ overnight. The hybridization mixture contained $0.8 \mu \mathrm{g} / \mathrm{ml}$ of DIG-labelled RNA antisense or sense probe, $50 \%(\mathrm{v} / \mathrm{v})$ deionized formamide, $300 \mathrm{mM}$ $\mathrm{NaCl}, 10 \mathrm{mM}$ Tris/HCl (pH 7.0), $10 \mathrm{mM} \mathrm{Na} \mathrm{PO}_{4}$ $(\mathrm{pH} 7.0), 50 \mathrm{mM}$ EDTA, $10 \%(\mathrm{w} / \mathrm{v})$ dextran sulfate, $200 \mu \mathrm{g} / \mathrm{ml}$ tRNA, 1x Denhardt's solution and 10 units $/ \mathrm{ml}$ RNase OutTM inhibitor (Invitrogen).

After the hybridization, the slides were washed in $2 \mathrm{x}$ $\mathrm{NaCl} / \mathrm{Cit}$ (300 mM NaCl, $30 \mathrm{mM}$ sodium citrate, $\mathrm{pH} 7.0$ ) at RT for $10 \mathrm{~min}$ followed by $1 \mathrm{x}$ and $0.5 \mathrm{x} \mathrm{NaCl} / \mathrm{Cit}$ treatment by slow shaking at $37^{\circ} \mathrm{C}$ for $10 \mathrm{~min}$. The washing was followed by treatment of the RNase A (Roche, $1 \mu \mathrm{g} / \mathrm{ml}$ in $10 \mathrm{mM}$ Tris/ $\mathrm{HCl}, 500 \mathrm{mM} \mathrm{NaCl}, 1 \mathrm{mM} \mathrm{Na} \mathrm{N}_{2}$ EDTA, $\mathrm{pH} 7.5$ ) at $37^{\circ} \mathrm{C}$ for $60 \mathrm{~min}$. Then the slides were washed four times in the same solution but without RNase A in a slow shaking at $37^{\circ} \mathrm{C}$ for $15 \mathrm{~min}$ and once in $2 \mathrm{x} \mathrm{NaCl} / \mathrm{Cit}$ at RT for $30 \mathrm{~min}$.

For the detection of hybridized probe, the slides were washed in Tris/ $\mathrm{NaCl}$ buffer $(100 \mathrm{mM}$ Tris/ $\mathrm{HCl}, 150 \mathrm{mM}$ $\mathrm{NaCl}, \mathrm{pH} 7.5)$ for $5 \mathrm{~min}$ and blocked with $3 \%(\mathrm{w} / \mathrm{v})$ blocking reagent (Dig Nucleic acid detection Kit, Roche) and $0.3 \%(\mathrm{v} / \mathrm{v})$ Triton $\mathrm{X}-100$ in Tris/ $\mathrm{NaCl}$ buffer in a water atmosphere at RT for $30 \mathrm{~min} .1 \mathrm{unit} / \mathrm{ml}$ of Anti-DIG-AP Fab fragments (Roche) in Tris/ $\mathrm{NaCl}$ buffer was added to the sections, mounted under parafilm and incubated in a water atmosphere at RT for $2 \mathrm{~h}$. The slides were washed at RT four times in Tris/ $\mathrm{NaCl}$ buffer for $10 \mathrm{~min}$ and in AP buffer $(100 \mathrm{mM}$ Tris/ $\mathrm{HCl}, 100 \mathrm{mM}$ $\mathrm{NaCl}, 50 \mathrm{mM} \mathrm{MgCl} 2, \mathrm{pH}$ 9.5) for $5 \mathrm{~min}$. For colour development, 2\% (v/v) NBT/BCIP substrate (Dig Nucleic acid detection Kit, Roche) and 1\% (v/v) Triton X-100 in AP buffer was dispersed on the sections, mounted with coverslips and incubated in a water atmosphere at RT in the dark overnight. The slides were washed with water, dehydrated in a graded series of ethanol, air-dried and then mounted with immersion oil and covered with coverslips. The sections were examined with a light microscope (Nikon Optiphot 2, Japan) and imaged with an Infinity $1-3 \mathrm{C}$ camera (Lumenera Corporatiom, Ottawa, Ontario, Canada), using the IMT iSolution Lite image-processing program (IMT i-Solution Inc., Vancouver, BC, Canada). The auto and manual tiling feature of image-processing program was used to combine separate images to one. Non-specific signal was observed in the remnants of the degenerated suspensors, ESR, and inner nucellar layers generated by fragmented nucleic acids as previously described in Vuosku et al. [50]. Adobe Photoshop CS5 was used to adjust contrast, brightness and colour uniformly to entire images.

\section{Quantification of gene expression}

The real-time reverse-transcription PCR analysis (Q-RTPCR) was used for the quantification of the CAT, RBR and $\beta G$ expression in immature seeds at the developmental stages of early and late embryogeny as well as in the embryos and megagametophytes of mature seeds. Being aware of the challenges in finding suitable endogenous reference genes for pine embryogenesis [51], both absolute and relative Q-RT-PCR analyses were used. For the determination of mRNA copy numbers in the absolute quantification, the standard curves were generated using serial 10-fold dilutions of synthesized RNA molecules to control variability during both RT and PCR steps of Q-RT-PCR runs. The DNA templates from which the RNA molecules could be transcribed were amplified by basic PCR procedure using gene-specific primers (Additional file 1: Table S3). The upstream primers contained T7 promoter sequence (TAATACGACTCACTA TAGGG) and the downstream primers contained poly(T) tail at their 5 'end. The DNA molecules were subsequently used as templates for in vitro transcription by T7 RNA polymerase. The numbers of standard RNA molecules added to the reverse-transcription reactions were calculated using the molecular weights of the oligonucleotides and Avogadro's constant $\left(6.022 \cdot 10^{23} \mathrm{~mol}^{-1}\right)$. In the relative quantification, ubiquinone $(U B I)$ and glyceraldehyde-3-phosphate dehydrogenase $(G A P D H)$ were used as endogenous reference genes (see Additional file 2 for details).

In the absolute Q-RT-PCR analysis (see Additional file 2 for details for the relative quantification), the number of biological replicates was 5, 5, 6, and 4 for early stage immature seeds, late stage immature seeds, embryos, and megagametophytes, respectively. The PCR amplification conditions of the gene fragment were optimized for the LightCycler ${ }^{\circledR} 2.0$ instrument (Roche Diagnostics), and the subsequent PCR runs showed a single PCR product during melting curve (The Tm Calling Analysis of Lightcycler 480 Software release 1.5.0 SP3) and electrophoretic analysis. The real-time PCR amplifications were performed using the LightCycler 480 SYBR Green I Master (Roche), $50 \mathrm{nM}$ gene specific primers (Additional file 1: Table S4) and $2 \mu \mathrm{l}$ cDNA in the reaction volume of $20 \mu \mathrm{l}$. The negative controls contained $2 \mu$ of molecular grade water instead of cDNA template. The real-time PCR 
amplification was initiated by incubation at $95^{\circ} \mathrm{C}$ for $10 \mathrm{~min}$ followed by 45 cycles: $10 \mathrm{~s}$ at $95^{\circ} \mathrm{C}, 10 \mathrm{~s}$ at $58^{\circ} \mathrm{C}$ and $5 \mathrm{~s}$ at $72^{\circ} \mathrm{C}$. Every PCR reaction was done as duplicate to control for the variability of PCR amplification and the coefficient variation, $\mathrm{CV} \%$, of technical replicates was $<2.5$. The Abs Quant/2nd Derivative analysis of Lightcycler 480 software release 1.5.0 SP3 was utilized to generate the crossing point and concentration values for each sample.

\section{Statistical analysis}

The mRNA copy numbers generated with the absolute Q-RT-PCR analysis were utilized in calculating the gene expression. The expression of studied genes was calculated by dividing the individual values with the mean number of transcripts in the early embryogeny, that is, value of one was given to the gene expression in the early embryogeny. The significance of difference between the early and late embryogeny and between the embryo and megagametophyte of mature seeds was examined using two sample $t$ test with the graphical user interface R Commander [52] in $\mathrm{R}$ software package (2.11.0) [53]. Log 10 transformation was conducted to variables not normally distributed.

\section{Results}

\section{Nuclear DNA fragmentation in ESR and nucellar layers}

In our previous study, we showed that megagametophyte cells in the ESR are destroyed by morphologically necrotic cell death and also the cells in the megagametophyte surrounding nucellar layers die during the Scots pine seed development [35]. Likewise, TUNEL positive nuclei were detected in the ESR cells and in the nucellar layers in this study (Additional file 3: Figure S2).

\section{Transient decrease of CAT expression in megagametophyte at late embryogeny}

The Scots pine CAT (EU513163) was amplified using zygotic embryo cDNA as a template. Previously, three $C A T$ genes have been found present in the angiosperm species tobacco (Nicotiana tabacum L.), Arabidopsis, maize, pumpkin (Cucurbita sp.) and rice (Oryza sativa L.) [54-58]. The angiosperm class I CATs are strongly expressed in photosynthetic tissues, whereas class II CATs are associated with vascular tissues. Class III CATs are expressed especially in seeds and reproductive tissues [25]. Scots pine $C A T$ showed high sequence similarity $(75 \%)$ with maize CAT1 belonging to class III.

Based on the Q-RT-PCR analysis, the number of CAT mRNA transcripts decreased significantly in developing Scots pine seeds when the embryogenesis proceeded from the early to the late stage $(P<0.001)$. In mature seeds, the number of $C A T$ transcripts was significantly greater in megagametophytes than in embryos $(P=0.02)$ (Figure 2A). At the early embryogeny, intense $C A T$ expression was localized in the cells of both the dominant embryo and subordinate embryos (Figure $2 \mathrm{~B}$ and $\mathrm{D}$ ) as well as in the cells of the megagametophyte and the nucellar layers (Figure 2B and E). At the late embryogeny, the CAT expression was still strong in the cells of the dominant embryo (Figure $2 \mathrm{C}$ and $\mathrm{G}$ ), whereas it was clearly diminished in the cells of the nucellar layers (Figure $2 \mathrm{C}$ and $\mathrm{F}$ ) and in the megagametophyte (Figure $2 \mathrm{C}$ and $\mathrm{G}$ ). In mature seeds the megagametophyte cells surrounding the corrosion cavity showed intense CAT expression whereas in the embryo, the expression was comparable to the late embryogeny (Figure 3). The specificity of the antisense CAT probe was confirmed by the absence of signals in the sections hybridized with the sense CAT probe (Additional file 4: Figure S3).

\section{Peroxidase and $\mathrm{H}_{2} \mathrm{O}_{2}$ localization}

At the early embryogeny, intense blue colour indicating $\mathrm{H}_{2} \mathrm{O}_{2}$ presence was observed in the seed coat, flight wing (Figure 4A), and cellular nucellus (Figure 4B). In addition, $\mathrm{H}_{2} \mathrm{O}_{2}$ was detected in the nucellar layers (Figure 4B), and megaspore membranes (Figure 4C). At the late embryogeny, $\mathrm{H}_{2} \mathrm{O}_{2}$ was still present in the seed coat and flight wing, but the extent was clearly diminished (Figure 4D). The seeds treated with Tris-acetate buffer were used as negative control (Figure 4E). Peroxidase activity was detected throughout the embryogenesis in the very same seed structures as $\mathrm{H}_{2} \mathrm{O}_{2}$ and, additionally, in the ESR cells and in the arrow-shaped region (ASR) of megagametophyte, suspensor cells, and subordinate embryos (Figure 5A and B, Additional file 5: Figure S4). For negative control DAB was excluded from the reaction buffer (Figure $5 \mathrm{C}$ ). The peroxidase localization with $\mathrm{DAB}$ and TMB protocol supplemented with $\mathrm{H}_{2} \mathrm{O}_{2}$ also gave comparable results (Additional file 5: Figure S4).

\section{Minute $R B R$ expression in dying megagametophyte cells in ESR}

The predicted Scots pine RBR protein showed 57\% identity with Arabidopsis RBR 1 protein. In Arabidopsis, only one $R B R$ gene has been found, and the presence of two distinct $R B R$ genes have been suggested to a unique feature of grasses [59]. In developing Scots pine seeds, there was overall low variation in the number of $R B R$ mRNA transcripts across the studied Scots pine seed material. The RBR transcript levels were comparable between early and late embryogenesis as well as between the embryos and megagametophytes of mature seeds when the expression was quantified with Q-RT-PCR (Figure 6A). The RBR expression was localized in both embryonic and megagametophyte cells throughout the embryogenesis excluding the dying megagametophyte cells in the ESR and the ASR cells (Figure 6B, C and D, Additional file 6: Figure S5). The RBR expression signal 

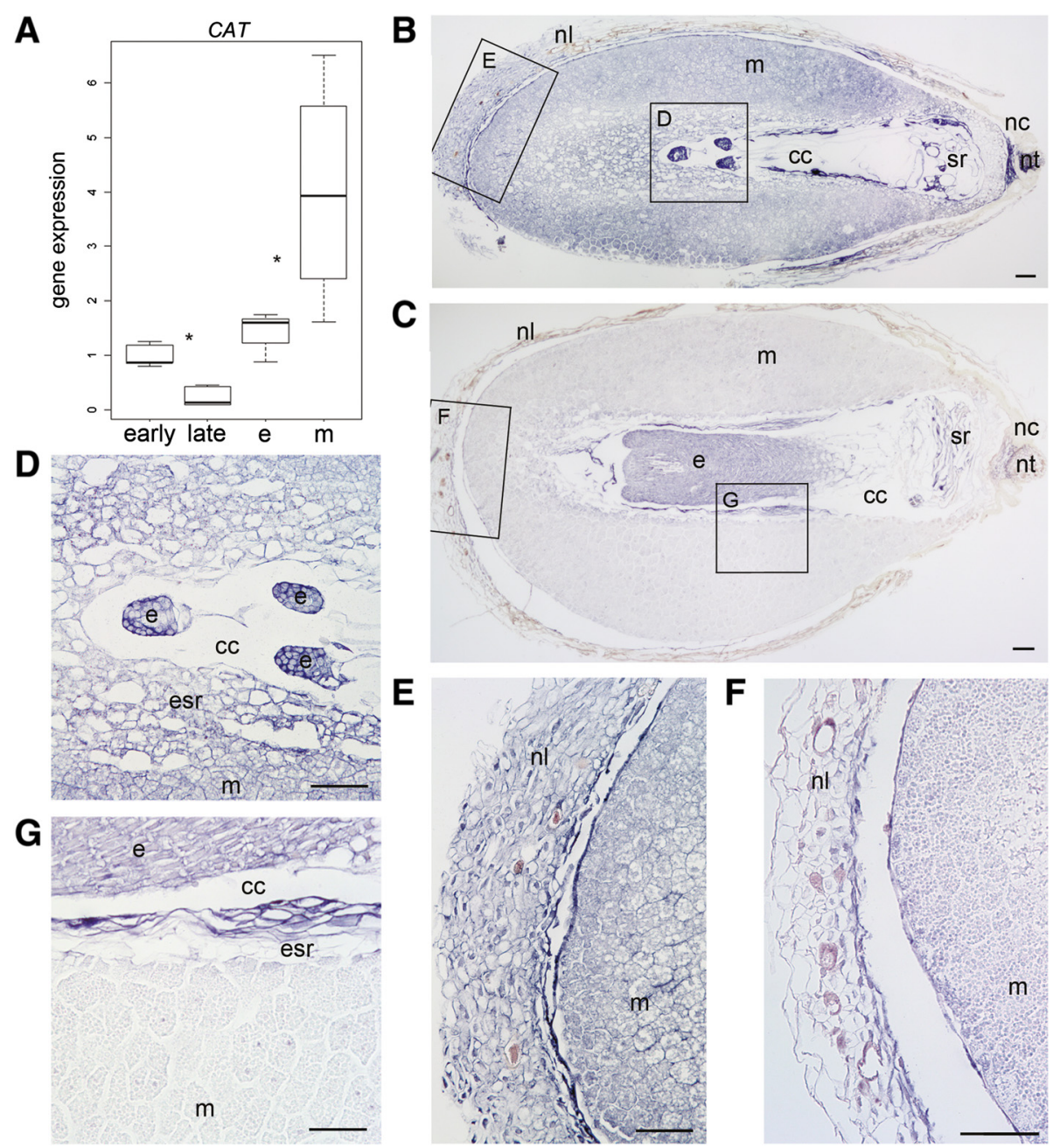

Figure 2 CAT expression in developing and mature Scots pine seeds. (A) The relative expression of CAT in developing seeds at the early and late embryogeny and in the embryos (e) and megagametophytes $(\mathrm{m})$ of mature seeds. The expression was based on mRNA copy numbers generated with the absolute Q-RT-PCR analysis and values presented were normalized using the expression at the early embryogeny. A star denotes significant $(P<0.05)$ difference in the expression. (B) The localization of CAT mRNAs by in situ hybridization with DIG-labelled RNA-probes (blue signal) in a developing Scots pine seed at the early embryogeny. (C) The localization of CAT mRNAs at the late embryogeny. (D) Intense CAT expression in the developing embryos and in the megagametophyte at the early embryogeny. (E) Intense CAT expression in the nucellar layers at the early embryogeny. (F) Minor CAT expression in the nucellar layers at the late embryogeny. (G) Intense CAT expression in the cells of the leading embryo and minor CAT expression in the megagametophyte cells at the late embryogeny. $c c=$ corrosion cavity, $\mathrm{e}=\mathrm{embryo}$, esr $=$ embryo surrounding region, $\mathrm{m}=$ megagametophyte, $\mathrm{nc}=$ nucellar cap, $\mathrm{nl}=$ nucellar layers, $\mathrm{nt}=$ cellular nucellus, $\mathrm{sr}=$ suspensor remnants. Bars: $100 \mu \mathrm{m}$.

was found weak in nucellar cells at early embryogeny, but showed more intensity at later stages of embryogenesis (Figure $6 \mathrm{E}$ and $\mathrm{F}$ ). The specificity of the antisense $R B R$ probe was confirmed by the absence of signals in the sections hybridized with the sense $R B R$ probe (Additional file 4: Figure S6).

\section{ATG5 expression in dying cells of ESR and nucellar layers}

In order to study the type of the cell death processes in the ESR of the megagametophyte and in the nucellar layers, we sequenced the complete coding sequence of the Scots pine ATG5 gene (KM046993) and localized ATG5 mRNA transcripts in developing Scots pine seeds at the early embryogeny and in mature seeds after two days of imbibition. The predicted Scots pine ATG5 protein showed 95\% identity with the Norway spruce ATG5 protein which has previously shown to be essential for autophagy and vacuolar cell death [44]. At the early embryogeny, the ATG5 expression was localized in both the ESR of the megagametophyte and the nucellar layers (Figure 7A). In a mature seed, ATG5 expressed still in the ESR, but also in the maturating tracheids (Figure 7B). The specificity of the antisense ATG5 probe was confirmed by the absence of signals in the sections hybridized with the sense ATG5 probe (Additional file 4: Figure S7). 


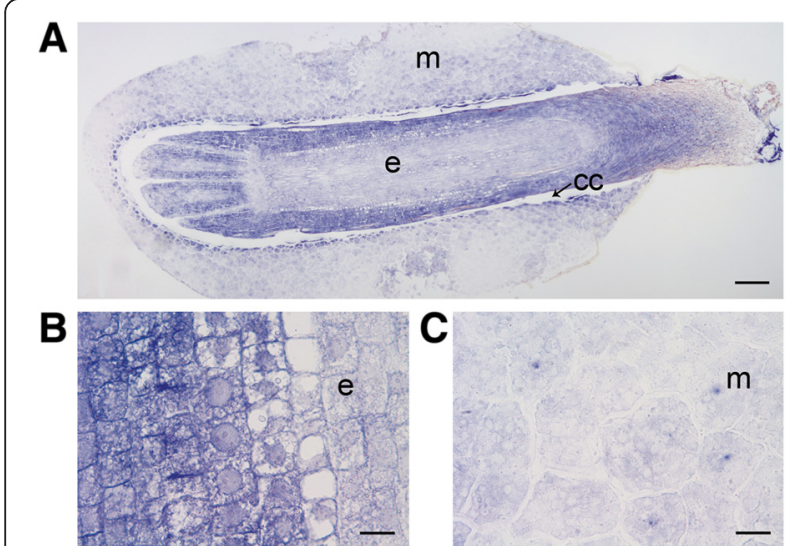

Figure 3 The localization of CAT mRNAs in a mature Scots pine seed. (A) Intense CAT expression (blue signal) in the embryo and in the megagametophyte cells surrounding the corrosion cavity. (B) Intense CAT expression in the embryonic cells. (C) Minor CAT expression in the cells in the inner part of the megagametophyte. $\mathrm{cC}=$ corrosion cavity, $\mathrm{e}=$ embryo, $\mathrm{m}=$ megagametophyte. Bars: (B, C) $20 \mu \mathrm{m}$ and (A) $200 \mu \mathrm{m}$.

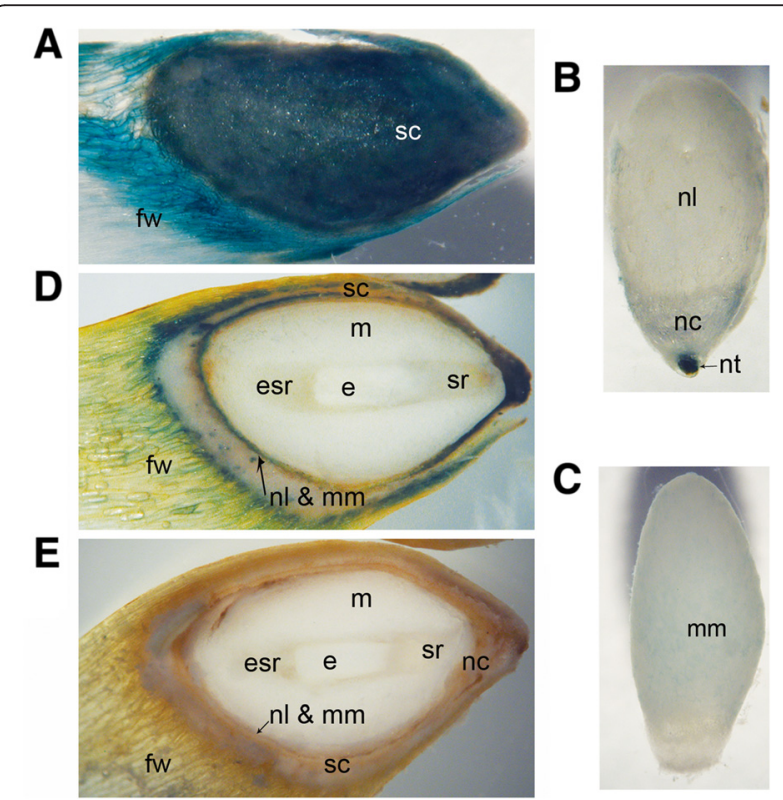

Figure 4 The localization of $\mathrm{H}_{2} \mathrm{O}_{2}$ in developing Scots pine seeds. (A) Intense blue colour from TMB indicates the presence of $\mathrm{H}_{2} \mathrm{O}_{2}$ in the seed coat and flight wing at the early embryogeny. (B) The localization of $\mathrm{H}_{2} \mathrm{O}_{2}$ in the nucellar cap, cellular nucellus, and in the nucellar layers at the early embryogeny. (C) The localization of $\mathrm{H}_{2} \mathrm{O}_{2}$ in the megaspore membranes at the early embryogeny. (D) The minor amount of $\mathrm{H}_{2} \mathrm{O}_{2}$ in the seed coat and flight wing and the large amount of $\mathrm{H}_{2} \mathrm{O}_{2}$ indicated by the dark blue colour in the nucellar layers at the late embryogeny. (E) The seed treated with Tris-acetate buffer without TMB. $c c=$ corrosion cavity, $\mathrm{e}=$ embryo, esr $=$ embryo surrounding region, $\mathrm{fw}=$ flight wing, $\mathrm{m}=$ megagametophyte, $\mathrm{mm}=$ megaspore membranes, $\mathrm{nc}=$ nucellar cap, $\mathrm{nl}=$ nucellar layers, $\mathrm{nt}=$ cellular nucellus, $\mathrm{sc}=$ seed coat, $\mathrm{sr}=$ suspensor remnants.

\section{A}

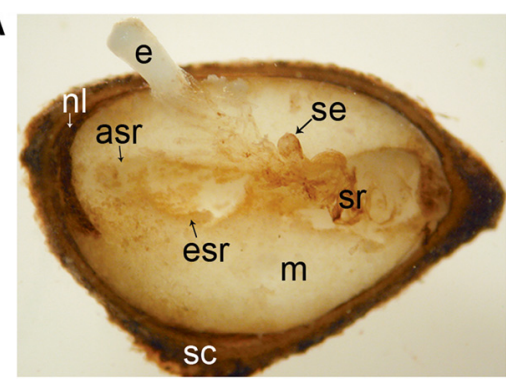

B

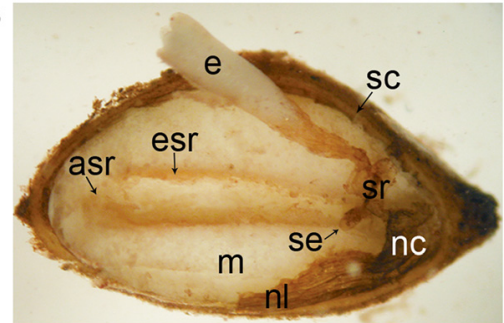

C

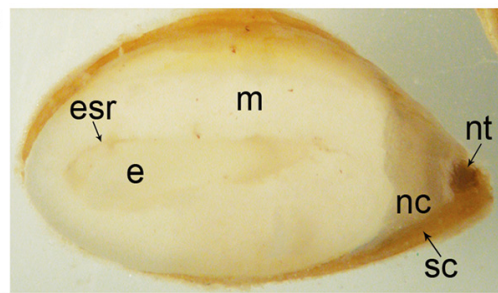

Figure 5 The localization of peroxidase activity in developing Scots pine seeds. (A, B) Oxidized DAB (brown colour) indicated peroxidase activity in the seed coat, nucellar layers, megagametophyte cells surrounding the corrosion cavity, suspensor cells and subordinate embryos at the early (A) and late (B) embryogeny. (C) The seed treated with the reaction buffer without DAB. asr = arrow-shaped region, $\mathrm{e}=$ embryo, esr = embryo surrounding region, $\mathrm{m}$ = megagametophyte, $\mathrm{mm}=$ megaspore membranes, $\mathrm{nc}=$ nucellar cap, $\mathrm{nl}=$ nucellar layers, $\mathrm{nt}=$ cellular nucellus, $\mathrm{sc}=$ seed coat, $\mathrm{se}=$ subordinate embryo, $\mathrm{sr}=$ suspensor remnants.

\section{Accumulation and release of starch and storage proteins during Scots pine seed development}

The Scots pine seed development comprises the accumulation of storage compounds such as starch and storage proteins. At the early embryogeny, the megagametophyte cells had only few storage proteins (Figure 8A) but during the late embryogenesis intensively stained protein bodies were found in the megagametophyte tissue (Figure 8B). However, the megagametophyte cells in ESR in addition to the cells in ASR did not pile up proteins during early embryogeny, but instead contained high quantity of starch (Figure $8 \mathrm{C}$ ). As the embryo development proceeded the cell wall and plasma membrane of megagametophyte cells in ESR were destroyed with the release of starch grains into the corrosion cavity. In dying cells, the cell wall weakening and breakdown seemed to be connected with the increased intensity of the $\beta G$ gene expression detected with in situ hybridization (Additional file 7: Figure S8, S9). In addition to the ESR and ASR, starch also 

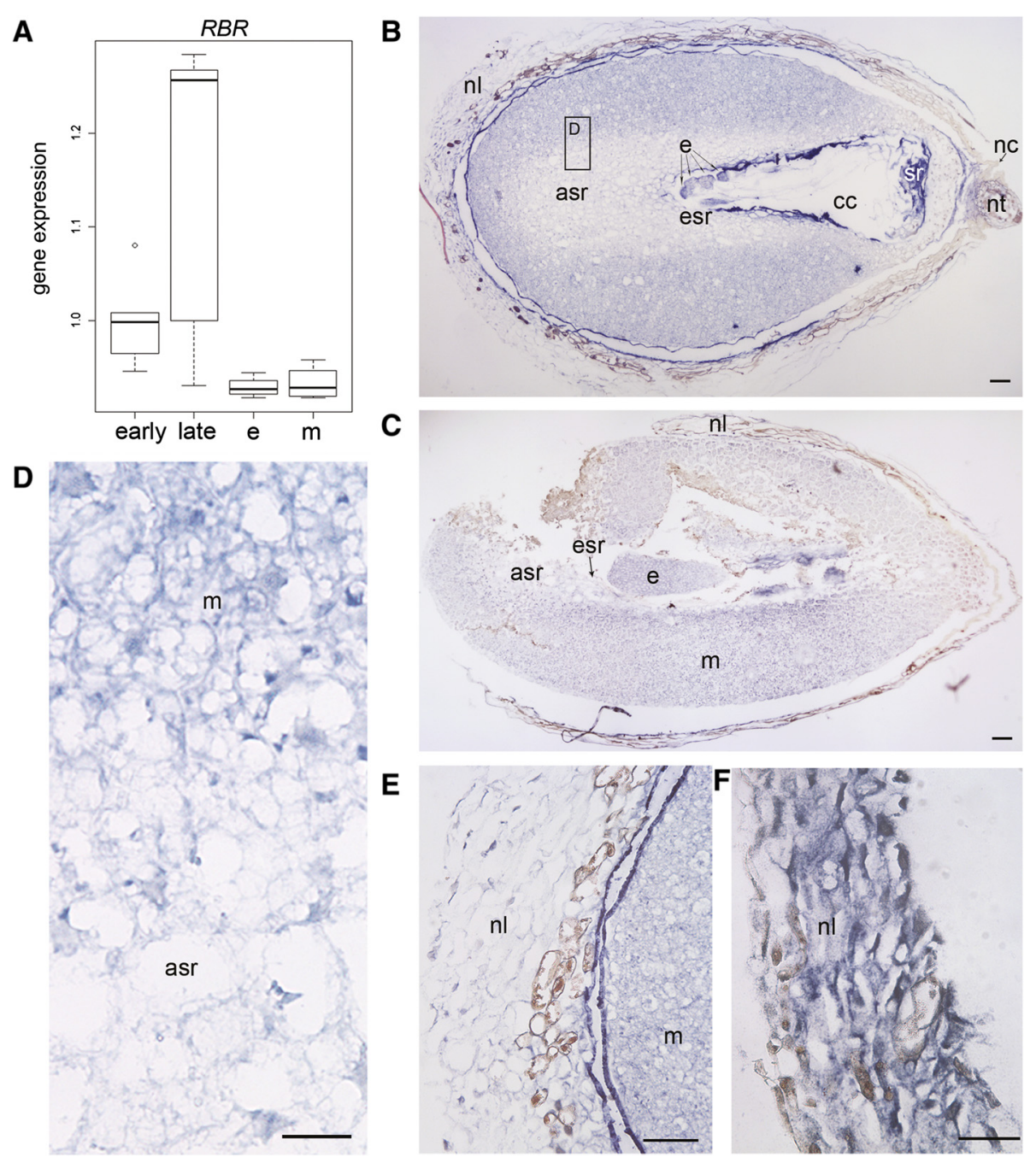

Figure 6 RBR expression in developing Scots pine seeds. (A) The relative expression of RBR in developing seeds at the early and late embryogeny and in the embryos (e) and megagametophytes $(\mathrm{m})$ of mature seeds. The expression was based on mRNA copy numbers generated with the absolute Q-RT-PCR analysis and values presented were normalized using the expression at the early embryogeny. (B) The localization of RBR mRNAs (blue signal) in a developing Scots pine seed at the early embryogeny. (C) The localization of RBR mRNAs at the late embryogeny. (D) Minor RBR expression in the ESR of the megagametophyte at the early embryogeny. (E) Weak RBR expression in the cells of the nucellar layers at the early embryogeny. (F) Intense RBR expression in the cells of the nucellar layers at the late embryogeny. asr = arrow-shaped region, $c c=$ corrosion cavity, e = embryo, esr = embryo surrounding region, $\mathrm{m}=$ megagametophyte, $\mathrm{nc}=$ nucellar cap, $\mathrm{nl}=$ nucellar layers, $\mathrm{nt}=$ cellular nucellus, $\mathrm{sr}=$ suspensor remnants. Bars: (D) $20 \mu \mathrm{m}$, (F) $50 \mu \mathrm{m}$, and (B, C, E) $100 \mu \mathrm{m}$.

accumulated into the cells of both the developing embryo and megagametophyte (Figure 8D).

\section{Discussion}

As an orthodox seed, a developing Scots pine seed experiences three characteristic features, embryo development, accumulation of reserve compounds and maturation/drying, which lead from a zygotic embryo to a mature, quiescent seed [60]. Both metabolic activity and moisture content fluctuate drastically during seed development [61-64]. Thus, the sources of ROS production, connected to basic cellular and specific seed developmental processes, in cells also vary [65]. During the seed development, the cell cycle is tightly controlled for proper growth and development [66] but also for cellular level oxidative stress responses [67]. Here, we show the tissue and developmental stage specific expression of the ATG5, CAT, and $R B R$ genes as well as the connection between the gene expressions and cell death programs during the Scots pine seed development.

The development of a viable Scots pine seed includes the strictly coordinated action of several cell death programs (reviewed by Vuosku et al. [68]). The autophagic PCD of subordinate embryos as well as their suspensor 


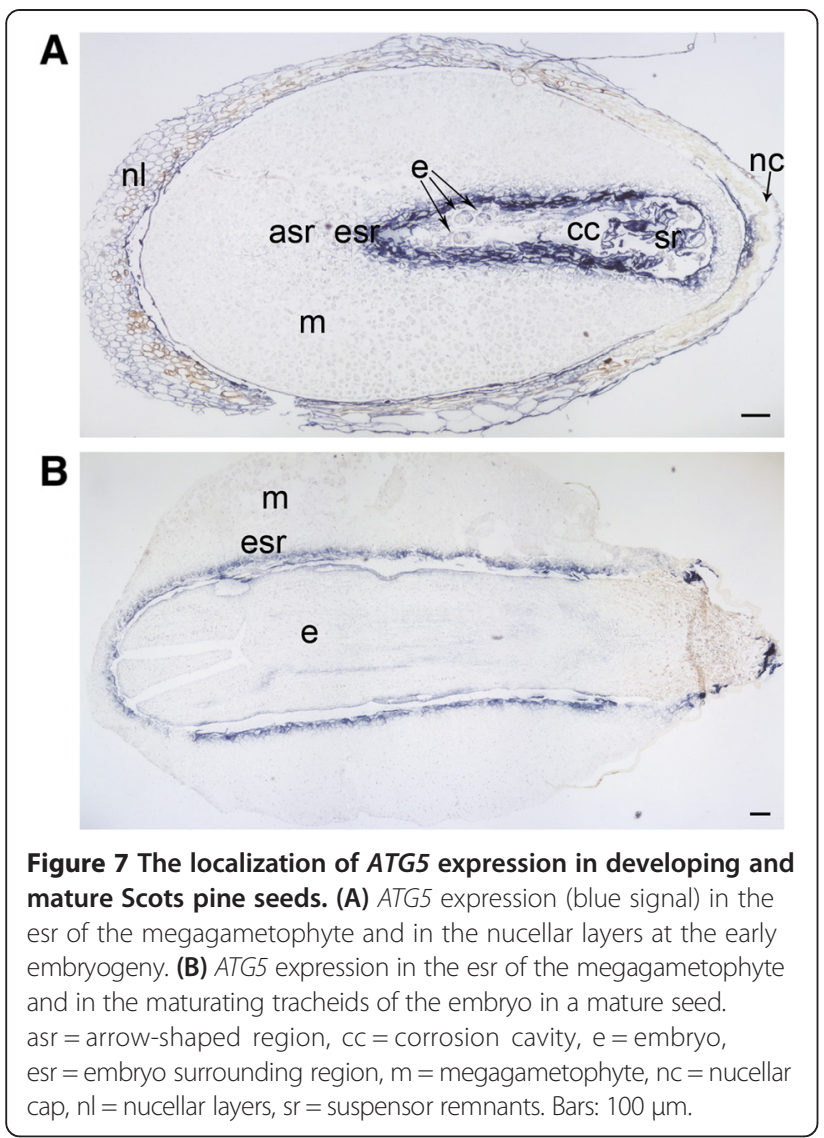

tissues is initiated already at early embryogeny [34]. The nucellar layers face destruction at late embryogeny [35] to be used as a nutrition for the surrounding tissues of the seed and later on to form an efficient barrier to the passage of water and against fungal infections [40,41]. The necrotic-like death of the megagametophyte cells in the ESR continues throughout the embryogenesis. In the present study, the ESR cells differed already at the early embryogeny from the other megagametophyte cells in the expression of $A T G 5, C A T, R B R$ and $\beta G$ genes as well as the storage compound distribution. The ESR cells had higher amount of starch and less storage proteins than the surrounding cells of the megagametophyte. The starch accumulation has been shown to precede PCD of the endosperm in several cereals [69-72] and in the perisperm of quinoa (Chenopodium quinoa Willd.) [73]. The role of starch accumulation may be more general in PCD: the endosperm cells of starch-deficient maize mutants contained more ethylene and faced accelerated PCD [69]. In cereals, the storage compounds are not evenly located in endosperm, but there is a gradient in the distribution of storage proteins and starch [69,74]. In a Scots pine seed, protein bodies and starch, however, filled all megagametophyte cells except the cells in the ESR at the late embryogeny.

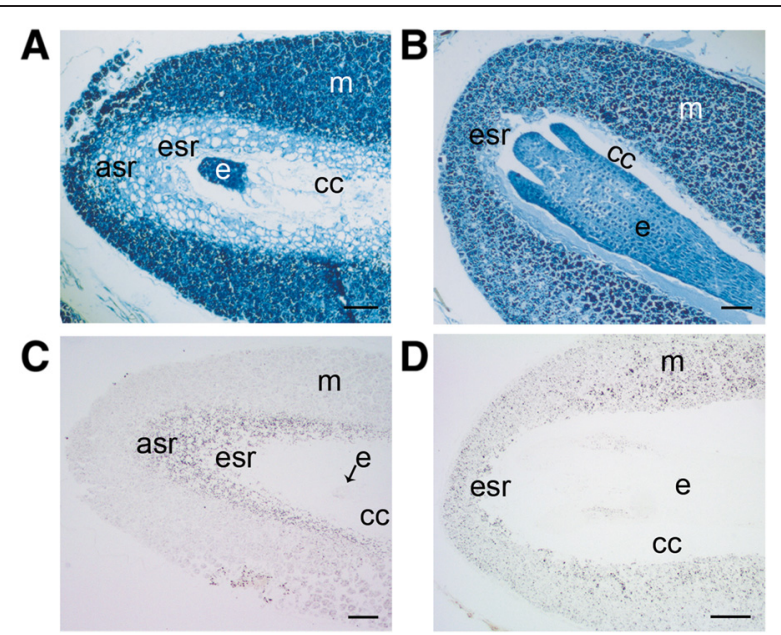

Figure 8 Histochemical localization of proteins by amido black and starch by potassium iodide-iodine in developing Scots pine seeds. (A) Megagametophyte cells with few protein storage vacuoles at the early embryogeny. (B) Megagametophyte cells stocked with protein storage vacuoles at the late embryogeny. (C) Megagametophyte cells with starch grains in the vicinity of the corrosion cavity at the early embryogeny. (D) Starch grains in the cotyledons and root meristem of a late embryo as well as in the megagametophyte. asr = arrow-shaped region, $c c=$ corrosion cavity, $\mathrm{e}=$ embryo, esr = embryo surrounding region, $\mathrm{m}=$ megagametophyte. Bars: (A, C) $100 \mu \mathrm{m}$ and (B, D) $200 \mu \mathrm{m}$.

Intense $\beta G$ expression was found in the ESR of the megagametophyte and in the nucellar layers which suggests that during the cell death processes $\beta G$ contributes to either weakening or breaking down of cell walls depending on the type and physiological function of the cell death. In Arabidopsis, cell wall associated $\beta G$ breaks down polysaccharides to soluble sugars, and is induced by both starvation [75] and senescence [76]. In barley (Hordeum vulgare L.), hydrolysis of $\beta$-linked oligosaccharides results in cell wall degradation in endosperm during seed germination [77]. Hence, $\beta G$ appears to contribute to both the degradation of oligosaccharides generated in cell wall turnover and release of monolignols from their glycosides for the stabilization of secondary cell wall by lignification [78].

Generally, CATs are considered as a sink for $\mathrm{H}_{2} \mathrm{O}_{2}$ $[25,79]$. In the present study, the tissue and developmental stage specific $C A T$ expression suggested an important role for CAT in enzymatic ROS protection in Scots pine seeds. CAT showed intense expression in megagametophyte cells at the early embryogeny simultaneously with the accumulation of starch and storage proteins. Interestingly, the $C A T$ expression signal faded out in the megagametophyte when the embryogenesis proceeded to the late stage but increased again during the imbibition phase of the seed germination. The transient decrease in the CAT expression co-occurred 
with slight DNA fragmentation in the nuclei of megagametophyte cells - that is to say, an incipient sign of cell death - detected in our previous study [35]. Unlike in the megagametophyte, $C A T$ expression was intense in the cells of developing embryos throughout the embryogenesis and also in embryonic cells of mature seeds. Previously, CAT protein has been purified from the megagametophyte of loblolly pine (Pinus taeda L.) seeds [80], and the CAT gene has also been found to be active in in vitro cultured Scots pine embryogenic cells [31]. It has been suggested that in white spruce (Picea glauca (Moench.) Voss) the interplay of CAT and the ubiquitin mediated proteolytic system regulates ROS production and subsequent cell death in the megagametophyte during germination [81].

The $\mathrm{H}_{2} \mathrm{O}_{2}$ localization overlapped with the ATG5 and $C A T$ localizations at early embryogeny in the nucellar layers which undergo PCD later during Scots pine seed development $[35,39]$. Together the CAT expression and the presence of peroxidases in several seed structures indicate active $\mathrm{H}_{2} \mathrm{O}_{2}$ scavenging, and moreover, strict regulation of $\mathrm{H}_{2} \mathrm{O}_{2}$ levels during the embryogenesis. Possibly, the $\mathrm{H}_{2} \mathrm{O}_{2}$ detected in the nucellar layers exceeded the detoxifying capacity of ROS detoxifying enzymes, including CAT, thus triggering $\mathrm{PCD}$, the mechanism also proposed by $\mathrm{He}$ and Kermode [81] for ROS mediated death of white spruce megagametophyte. Additionally, $\mathrm{H}_{2} \mathrm{O}_{2}$ can be involved in growth and developmental processes due to its role as an important signalling molecule [82]. Previously, high CAT activity has been detected in durum wheat (Triticum durum Desf.) kernels before the start of maturation drying [83], and CAT has also found to affect seed desiccation of sunflower (Helianthus annuus L.) by preventing dehydration-related oxidative damage [84]. Here, the reduced CAT expression in the megagametophyte cells at the late embryogeny, however, suggests that in Scots pine seeds the CAT protection against $\mathrm{H}_{2} \mathrm{O}_{2}$ damage was more connected to active metabolism than to dehydration-related oxidative stress during the seed desiccation.

We found that $R B R$ expression remain quite stable throughout the Scots pine embryogenesis as well as in both the embryos and megagametophytes of mature seeds. In Arabidopsis, the loss of RBR function is gametophyte-lethal because the mature unfertilized mutant megagametophyte fails to arrest mitosis and undergoes excessive nuclear proliferation in the embryo sac [85]. In the maize endosperm, the down-regulation of $R B R 1$ by RNAi enhanced cell death and stimulated both the mitotic and endoreduplication cell cycles. Furthermore, DNA content was increased $43 \%$ by the down regulation of RBR1 during endosperm development, whereas storage protein content and kernel weight were essentially not affected
[15]. In endoreduplication, a cell replicates chromosomal DNA without an intervening mitosis resulting in a higher ploidy level [86]. Pinus sp. exhibits the uniform haploid megagametophyte compared to the diploid DNA content of the corresponding embryo [87-89] indicating that no endoreduplication occurs in the megagametophyte cells. In the present study, the minor $R B R$ expression found in the ESR suggests that $R B R$ down regulation precedes cell death in Scots pine megagametophyte cells. The dying cells of the nucellar layers, however, showed intense $R B R$ expression at the late embryogeny. The opposite $R B R$ expression goes together with the different morphological features and different magnitudes of cell corpse processing in the ESR of the megagametophyte and in the nucellar layers emphasizing the specific developmental tasks of the cell death processes. Unlike in the ESR, cell death in the nucellar layers may be connected to oxidative stress leading to cell cycle arrest and preventing the replication of damaged DNA by intense $R B R$ expression. Further protein level studies are, however, needed to confirm the possible role of RBR in the cell death processes during the Scots pine seed development. The stable RBR expressions detected in the present study is concordant with the previous findings revealing that in mammalian cells the $\mathrm{pRB}$ protein exhibits only slight variation at the gene expression level but significant differences in the protein phosphorylation status [90].

\section{Conclusions}

Starch accumulation precedes necrotic-like PCD in the ESR cells of the Scots pine megagametophyte, a phenomenon detected previously in the endosperm and perisperm of angiosperm seeds. Furthermore, the changes in the RBR, ATG5 and $\beta G$ expressions specifically in the cells doomed to death via morphologically necrotic cell death in the ESR and ASR of the megagametophyte suggest the genetic regulation of developmental necrosis. The results suggest that the function of CAT in the megagametophyte could be connected to the ongoing metabolism, whereas the continuous $C A T$ expression in the embryo underlines the importance of CAT in the preventing of the transfer of $\mathrm{H}_{2} \mathrm{O}_{2}$ damaged components, especially DNA, to the next generation.

\section{Additional files}

Additional file 1: PCR primers for in situ mRNA hybridization assays and Q-RT-PCR.

Additional file 2: The determination of gene expression using relative quantification.

Additional file 3: Detection of nuclear DNA fragmentation by TUNEL assay. 


\section{Additional file 4 In situ mRNA hybridizations with sense probes. Additional file 5: Verification of DAB visualized peroxidase location with $\mathrm{H}_{2} \mathrm{O}_{2}$ supplemented TMB.}

Additional file 6: $R B R$ localization with in situ mRNA hybridization in the transition from early to late developmental stage of the Scots pine seed development.

Additional file 7: $\beta$ G expression in developing Scots pine seeds.

\section{Abbreviations}

ATG: Autophagy; $\beta$ G: $\beta$-glucosidase; CAT: Catalase; ESR: Embryo surrounding region; PCD: Programmed cell death; RBR: Retinoblastoma related protein ROS: Reactive oxygen species.

\section{Competing interests}

The authors declare that they have no competing interests.

\section{Authors' contributions}

JV conceived and designed the study. JV, AJ and SS carried out the histochemical stainings and JK and JV the in situ mRNA hybridizations. JV and SS conducted the Q-RT-PCR runs. JV and SS analysed the results and drafted the manuscript with TS and $\mathrm{HH}$. All authors read and approved the final manuscript.

\section{Acknowledgements}

We thank our colleagues Dr. Anneli Kauppi from the University of Oulu and Dr. Eila Tillman-Sutela from Luke for their help and interest during the research. We are also grateful to Ms Eeva Pihlajaviita, Luke, Parkano Unit, for her skillful technical assistance, and to the personnel of Luke at the Punkaharju Unit for conducting the collections of the research material. The research was funded by the Academy of Finland (Project 121994 to TS), Thule Institute at University of Oulu (to $\mathrm{HH}$ ) and by grants from the Taina Kuusi Foundation, the Finnish Cultural Foundation and the Niemi Foundation (to $\mathrm{J}$ ). The research was conducted as a part of the Bioeconomy Research Community of the University of Oulu.

\section{Author details}

${ }^{1}$ Genetics and Physiology Unit, University of Oulu, P.O. Box 3000, Fl-90014 Oulu, Finland. ${ }^{2}$ Natural Resources Institute Finland (Luke), Parkano Unit, Kaironiementie 15, Fl-39700 Parkano, Finland. ${ }^{3}$ Current address: Natural Resources Institute Finland (Luke), Rovaniemi Unit, Fl-96301 Rovaniemi, Finland.

Received: 5 December 2014 Accepted: 18 February 2015

Published online: 15 March 2015

\section{References}

1. Greenberg JT. Programmed cell death: a way of life for plants. Proc Natl Acad Sci U S A. 1996;93(22):12094-7.

2. Jones AM. Programmed cell death in development and defense. Plant Physiol. 2001;125(1):94-7

3. Lam E. Programmed cell death in plants: orchestrating an intrinsic suicide program within walls. Crit Rev Plant Sci. 2008;27(6):413-23.

4. Coll NS, Epple P, Dangl JL. Programmed cell death in the plant immune system. Cell Death Differ. 2011;18(8):1247-56.

5. Kroemer G, Galluzzi L, Vandenabeele P, Abrams J, Alnemri ES, Baehrecke EH, et al. Classification of cell death: recommendations of the nomenclature committee on cell death. Cell Death Differ. 2009:16(1):3-11.

6. van Doorn WG, Beers EP, Dangl JL, Franklin-Tong VE, Gallois P, Hara-Nishimura I, et al. Morphological classification of plant cell deaths. Cell Death Differ. 2011;18(8):1241-6.

7. van Doorn WG. Classes of programmed cell death in plants, compared to those in animals. J Exp Bot. 2011:62(14):4749-61.

8. Pennell RI, Lamb C. Programmed cell death in plants. Plant Cell. 1997:9(7):1157-68

9. Zong WX, Thompson CB. Necrotic death as a cell fate. Genes Dev. 2006;20(1):1-15.

10. Berghe TV, Linkermann A, Jouan-Lanhouet S, Walczak H, Vandenabeele P. Regulated necrosis: the expanding network of non-apoptotic cell death pathways. Nat Rev Mol Cell Biol. 2014;15(2):135-47.
11. Golstein P, Kroemer G. Cell death by necrosis: towards a molecular definition. Trends Biochem Sci. 2007:32(1):37-43.

12. He X, Kermode AR. Proteases associated with programmed cell death of megagametophyte cells after germination of white spruce (Picea glauca) seeds. Plant Mol Biol. 2003;52(4):729-44.

13. Tsiatsiani L, Van Breusegem F, Gallois P, Zavialov A, Lam E, Bozhkov PV. Metacaspases. Cell Death Differ. 2011;18(8):1279-88.

14. Hackenberg T, Juul T, Auzina A, Gwizdz S, Malolepszy A, Van Der Kelen K, et al. Catalase and NO CATALASE ACTIVITY1 promote autophagy-dependent cell death in Arabidopsis. Plant Cell. 2013;25(11):4616-26.

15. Sabelli PA, Liu Y, Dante RA, Lizarraga LE, Nguyen HN, Brown SW, et al. Control of cell proliferation, endoreduplication, cell size, and cell death by the retinoblastoma-related pathway in maize endosperm. Proc Natl Acad Sci U S A. 2013;110(19):E1827-36.

16. Dat JF, Pellinen R, Beeckman T, Van De Cotte B, Langebartels C, Kangasjärvi J, et al. Changes in hydrogen peroxide homeostasis trigger an active cell death process in tobacco. Plant J. 2003:33(4):621-32.

17. Van Breusegem F, Dat JF. Reactive oxygen species in plant cell death. Plant Physiol. 2006;141(2):384-90.

18. de Pinto MC, Locato $V$, de Gara L. Redox regulation in plant programmed cell death. Plant Cell Environ. 2012:35(2):234-44.

19. Møller IM, Jensen PE, Hansson A. Oxidative modifications to cellular components in plants. Annu Rev Plant Biol. 2007:58:459-81.

20. Chamnongpol S, Willekens H, Moeder W, Langebartels C, Sandermann Jr H, Van Montagu $\mathrm{M}$, et al. Defense activation and enhanced pathogen tolerance induced by $\mathrm{H}_{2} \mathrm{O}_{2}$ in transgenic tobacco. Proc Natl Acad Sci U S A. 1998;95(10):5818-23.

21. Rizhsky L, Hallak-Herr E, Van Breusegem F, Rachmilevitch S, Barr JE, Rodermel S, et al. Double antisense plants lacking ascorbate peroxidase and catalase are less sensitive to oxidative stress than single antisense plants lacking ascorbate peroxidase or catalase. Plant J. 2002;32(3):329-42.

22. Vandenabeele S, Van Der Kelen K, Dat J, Gadjev I, Boonefaes T, Morsa S, et al. A comprehensive analysis of hydrogen peroxide-induced gene expression in tobacco. Proc Natl Acad Sci U S A. 2003:100(26):16113-8.

23. Vanderauwera $S$, Zimmermann $P$, Rombauts $S$, Vandenabeele $S$, Langebartels C, Gruissem W, et al. Genome-wide analysis of hydrogen peroxide-regulated gene expression in Arabidopsis reveals a high light-induced transcriptional cluster involved in anthocyanin biosynthesis. Plant Physiol. 2005;139(2):806-21.

24. Apel K, Hirt H. Reactive oxygen species: metabolism, oxidative stress, and signal transduction. Annu Rev Plant Biol. 2004;55:373-99.

25. Mhamdi A, Queval G, Chaouch S, Vanderauwera S, Van Breusegem F, Noctor G. Catalase function in plants: a focus on Arabidopsis mutants as stress-mimic models. J Exp Bot. 2010;61(15):4197-220.

26. Michelet $L$, Roach $T$, Fischer BB, Bedhomme M, Lemaire SD, Krieger-Liszkay A. Down-regulation of catalase activity allows transient accumulation of a hydrogen peroxide signal in Chlamydomonas reinhardtii. Plant Cell Environ. 2013;36(6):1204-13.

27. Gutzat R, Borghi L, Gruissem W. Emerging roles of RETINOBLASTOMARELATED proteins in evolution and plant development. Trends Plant Sci. 2012;17(3):139-48

28. Friend SH, Bernards R, Rogelj S, Weinberg RA, Rapaport JM, Albert DM, et al. A human DNA segment with properties of the gene that predisposes to retinoblastoma and osteosarcoma. Nature. 1986;323(6089):643-6.

29. Morris EJ, Dyson NJ. Retinoblastoma protein partners. In Advances in Cancer Research. Edited by Anonymous 2001:1-54. [Anonymous, vol 82].

30. Sabelli PA, Larkins BA. Regulation and function of retinoblastoma-related plant genes. Plant Sci. 2009:177(6):540-8

31. Vuosku J, Suorsa M, Ruottinen M, Sutela S, Muilu-Mäkelä R, Julkunen-Tiitto R, et al. Polyamine metabolism during exponential growth transition in Scots pine embryogenic cell culture. Tree Physiol. 2012;32:1274-87.

32. Fath $\mathrm{A}$, Bethke $\mathrm{P}$, Lonsdale J, Meza-Romero R, Jones R. Programmed cell death in cereal aleurone. Plant Mol Biol. 2000;44(3):255-66.

33. Young TE, Gallie DR. Programmed cell death during endosperm development. Plant Mol Biol. 2000;44(3):283-301.

34. Filonova $L H$, von Arnold S, Daniel G, Bozhkov PV Programmed cell death eliminates all but one embryo in a polyembryonic plant seed. Cell Death Differ. 2002:9(10):1057-62.

35. Vuosku J, Sarjala T, Jokela A, Sutela S, Sääskilahti M, Suorsa M, et al. One tissue, two fates: different roles of megagametophyte cells during Scots pine embryogenesis. J Exp Bot. 2009;60(4):1375-86. 
36. Buchholz J. Origin of cleavage polyembryony in conifers. Bot Gaz. 1926;81:55-71.

37. Sarvas R. Investigations on the flowering and seed crop of Pinus silvestris. Comm Inst Forest Fenn. 1962;53:1-198.

38. Costa LM, Gutierrez-Marcos JF, Dickinson HG. More than a yolk: the short life and complex times of the plant endosperm. Trends Plant Sci. 2004;9(10):507-14.

39. Hiratsuka R, Yamada Y, Terasaka O. Programmed cell death of Pinus nucellus in response to pollen tube penetration. J Plant Res. 2002;115(1118):141-8.

40. Tillman-Sutela E, Kauppi A. The significance of structure for imbibition in seeds of the Norway spruce, Picea abies (L.) Karst. Trees-Struct Funct. 1995:9(5):269-78.

41. Tillman-Sutela E, Kauppi A. The morphological background to imbibition in seeds of Pinus sylvestris L. of different provenances. Trees-Struct Funct. 1995;9(3):123-33.

42. Bozhkov PV, Filonova LH, Suarez MF, Helmersson A, Smertenko AP, Zhivotovsky $B$, et al. VEIDase is a principal caspase-like activity involved in plant programmed cell death and essential for embryonic pattern formation. Cell Death Differ. 2004;11(2):175-82.

43. Suarez MF, Filonova LH, Smertenko A, Savenkov El, Clapham DH, Von Arnold S, et al. Metacaspase-dependent programmed cell death is essential for plant embryogenesis. Curr Biol. 2004;14(9):R339-40.

44. Minina EA, Filonova LH, Fukada K, Savenkov El, Gogvadze V, Clapham D, et al. Autophagy and metacaspase determine the mode of cell death in plants. J Cell Biol. 2013;203:917-27.

45. Barceló AR. Hydrogen peroxide production is a general property of the lignifying xylem from vascular plants. Ann Botany. 1998;82(1):97-103.

46. Singh H. Embryology of gymnosperms. Berlin: Borntrager; 1978.

47. Fisher DB. Protein staining of ribboned epon sections for light microscopy Histochemie. 1968;16:92-6.

48. Jensen WA. Botanical histochemistry. San Francisco: W.H. Freeman; 1962.

49. Young ID, Ailles L, Deugau K, Kisilevsky R. Transcription of cRNA for in situ hybridization from polymerase chain reaction-amplified DNA. Lab Invest. 1991;64(5):709-12.

50. Vuosku J, Sutela S, Sääskilahti M, Kestilä J, Jokela A, Sarjala T, et al. Dealing with the problem of non-specific in situ mRNA hybridization signals associated with plant tissues undergoing programmed cell death. BMC Plant Methods. 2010;6:7.

51. Gonçalves S, Cairney J, Maroco J, Oliveira MM, Miquel C. Evaluation of control transcripts in real-time RT-PCR expression analysis during maritime pine embryogenesis. Planta. 2005;222(3):556-63.

52. Fox J. The R commander: a basic-statistics graphical user interface to R. J Stat Softw. 2005;14(9).

53. Ihaka R, Gentleman R. R: a language for data analysis and graphics. J Comput Graph Stat. 1996;5(3):299-314

54. Willekens $\mathrm{H}$, Inzé $\mathrm{D}$, Vanmontagu M, van Camp W. Catalases in plants. Mol Breed. 1995; 1(3):207-28.

55. Frugoli JA, Zhong HH, Nuccio ML, McCourt P, McPeek MA, Thomas TL, et al. Catalase is encoded by a multigene family in Arabidopsis thaliana (L) Heynh. Plant Physiol. 1996:112(1):327-36.

56. Guan LQ, Scandalios JG. Molecular evolution of maize catalases and their relationship to other eukaryotic and prokaryotic catalases. J Mol Evol. 1996;42(5):570-9

57. Esaka M, Yamada N, Kitabayashi M, Setoguchi Y, Tsugeki R, Kondo M, et al. CDNA cloning and differential gene expression of three catalases in pumpkin. Plant Mol Biol. 1997:33(1):141-55.

58. Iwamoto $\mathrm{M}$, Higo $\mathrm{H}$, Higo K. Differential diurnal expression of rice catalase genes: the 5 -flanking region of CatA is not sufficient for circadian control. Plant Sci. 2000;151(1):39-46

59. Sabelli PA, Larkins BA. Grasses like mammals? Redundancy and compensatory regulation within the retinoblastoma protein family. Cell Cycle. 2006;5(4):352-5.

60. Berjak P, Pammenter NM. Orthodox and recalcitrant seeds. In Vozzo JA, editor. Tropical tree seed manual. Washington DC, USA: USDA Forest Service; 2003:137-47.

61. Kapik RH, Dinus RJ, Dean JFD. Abscisic acid and zygotic embryogenesis in Pinus taeda. Tree Physiol. 1995;15(7-8):485-90.

62. Carrier DJ, Kendall EJ, Bock CA, Cunningham JE, Dunstan DI. Water content, lipid deposition, and (+)-abscisic acid content in developing white spruce seeds. J Exp Bot. 1999;50(337):1359-64.

63. Silveira V, Balbuena TS, Santa-Catarina C. Floh EIS, Guerra MP, Handro W. Biochemical changes during seed development in Pinus taeda L. Plant Growth Regul. 2004:44:147-56.

64. Vuosku J, Jokela A, Läärä E, Sääskilahti M, Muilu R, Sutela S, et al. Consistency of polyamine profiles and expression of arginine decarboxylase in mitosis during zygotic embryogenesis of Scots pine. Plant Physiol. 2006;142(3):1027-38.
65. Bailly C, El-Maarouf-Bouteau H, Corbineau F. From intracellular signaling networks to cell death: the dual role of reactive oxygen species in seed physiology. Comptes Rendus - Biol. 2008;331(10):806-14.

66. Inzé D, De Veylder L. Cell cycle regulation in plant development. Annu Rev Genet. 2006;40:77-105

67. Reichheld J, Vernoux T, Lardon F, Van Montagu M, Inzé D. Specific checkpoints regulate plant cell cycle progression in response to oxidative stress. Plant J. 1999:17(6):647-56.

68. Vuosku J, Sutela S, Tillman-Sutela E, Kauppi A, Jokela A, Sarjala T, et al. Pine embryogenesis - many licences to kill for a new life. Plant Sign Behav. 2009; 4(10):928-32

69. Young TE, Juvik JA, DeMason DA. Changes in carbohydrate composition and a-amylase expression during germination and seedling growth of starch-deficient endosperm mutants of maize. Plant Sci. 1997;129(2):175-89.

70. Young TE, Gallie DR. Analysis of programmed cell death in wheat endosperm reveals differences in endosperm development between cereals. Plant Mol Biol. 1999:39(5):915-26.

71. Li CY, Li WH, Li C, Gaudet DA, Laroche A, Cao LP, et al. Starch synthesis and programmed cell death during endosperm development in triticale (XTriticosecale Wittmack). J Integr Plant Biol. 2010;52(7):602-15.

72. Xu SB, Yu HT, Yan LF, Wang T. Integrated proteomic and cytological study of rice endosperms at the storage phase. J Proteome Res. 2010;9(10):4906-18

73. López-Fernández MP, Maldonado S. Ricinosomes provide an early indicator of suspensor and endosperm cells destined to die during late seed development in quinoa (Chenopodium quinoa). Ann Bot. 2013;112(7):1253-62.

74. Tosi P, Gritsch CS, He J, Shewry PR. Distribution of gluten proteins in bread wheat (Triticum aestivum) grain. Ann Bot. 2011;108(1):23-35.

75. Lee EJ, Matsumura Y, Soga K, Hoson T, Koizumi N. Glycosyl hydrolases of cell wall are induced by sugar starvation in Arabidopsis. Plant Cell Physiol. 2007;48(3):405-13.

76. Mohapatra PK, Patro L, Raval MK, Ramaswamy NK, Biswal UC, Biswal B. Senescence-induced loss in photosynthesis enhances cell wall B-glucosidase activity. Physiol Plantarum. 2010;138(3):346-55

77. Leah R, Kigel J, Svendsen I, Mundy J. Biochemical and molecular characterization of a barley seed B- glucosidase. J Biol Chem. 1995;270(26):15789-97.

78. Cairns JRK, Esen A. B-Glucosidases. Cell Mol Life Sci. 2010;67(20):3389-405.

79. Mhamdi A, Noctor G, Baker A. Plant catalases: peroxisomal redox guardians. Arch Biochem Biophys. 2012;525(2):181-94.

80. Mullen RT, Gifford DJ. Purification and characterization of catalase from loblolly pine (Pinus taeda L.) megagametophytes. Plant Physiol. 1993:103(2):477-83.

81. He X, Kermode AR. Programmed cell death of the megagametophyte during post-germinative growth of white spruce (Picea glauca) seeds is regulated by reactive oxygen species and the ubiquitin-mediated proteolytic system. Plant Cell Physiol. 2010:51(10):1707-20.

82. Petrov VD, Van Breusegem F. Hydrogen peroxide-a central hub for information flow in plant cells. AoB Plants. 2012;pls014.

83. De Gara L, De Pinto MC, Moliterni VMC, D'Egidio MG. Redox regulation and storage processes during maturation in kernels of Triticum durum. J Exp Bot. 2003;54(381):249-58.

84. Bailly C, Leymarie J, Lehner A, Rousseau S, Côme D, Corbineau F. Catalase activity and expression in developing sunflower seeds as related to drying J Exp Bot. 2004:55(396):475-83.

85. Ebol C, Mariconti L, Gruissem W. Plant retinoblastoma homologues control nuclear proliferation in the female gametophyte. Nature. 2004:429(6993):776-80

86. Lee HO, Davidson JM, Duronio RJ. Endoreplication: polyploidy with purpose. Genes Dev. 2009;23(21):2461-77.

87. Bino RJ, Lanteri S, Verhoeven HA, Kraak HL. Flow cytometric determination of nuclear replication stage in seed tissues. Ann Bot. 1993;72(2):181-7.

88. Wakamiya I, Newton RJ, Johnston JS, Price HJ. Genome size and environmental factors in the genus Pinus. Am J Bot. 1993;80(11):1235-41

89. Pichot C, El Maataoui M. Flow cytometric evidence for multiple ploidy levels in the endosperm of some gymnosperm species. Theor Appl Genet. 1997:94(6-7):865-70.

90. Miskolczi P, Lendvai Á, Horváth GV, Pettkó-Szandtner A, Dudits D. Conserved functions of retinoblastoma proteins: from purple retina to green plant cells. Plant Sci. 2007:172(4):671-83. 